\title{
Direct Carbon Fuel Cell-Cleaner and Efficient Future Power Generation Technology
}

\author{
Uzair Ibrahim $^{1 *}$ and Ahsan Ayub ${ }^{2}$ \\ ${ }^{1}$ Dept. of Chemical and Material Engineering, National University of Sciences and Technology, \\ Islamabad, Pakistan \\ ${ }^{2}$ US. Pakistan Center for Advanced Studies in Energy, National University of Sciences and Technology, \\ Islamabad, Pakistan
}

* Corresponding Author email: ibrahimuzair@ymail.com

Article History

Received: 09 October 2018

Revised: 17 February 2019

Accepted: 22 February 2019

Published: 23 February 2019

Student(s)

- Uzair Ibrahim

Academic Year: 2017-18

Course Level: Bachelor

Course Name: Chemical Engineering

Course year: $4^{\text {th }}$ year $/ 8^{\text {th }}$ Semester

Mentor(s)

- Ahsan Ayub

\section{ABSTRACT}

Increasing greenhouse effect due to the burning of fossil fuels has stirred the attention of researchers towards cleaner and efficient technologies. Direct carbon fuel cell (DCFC) is one such emerging technology that could generate electricity from solid carbon like coal and biogas in a more efficient and environmental-friendly way. The mechanism involves electrochemical oxidation of carbon to produce energy and highly pure carbon dioxide. Due to higher purity, the produced carbon dioxide can be captured easily to avoid its release in the environment. The carbon dioxide is produced in a gaseous state while the fuel used is in a solid state. Due to different phases, all of the fuel can be recovered from the cell and can be reused, ensuring complete $(100 \%)$ fuel utilization with no fuel losses. Moreover, DCFC operates at a temperature lower than conventional fuel cells. The electric efficiency of a DCFC is around $80 \%$ which is nearly double the efficiency of coal thermal plant. In addition, DCFC produces pure carbon dioxide as compared to the thermal power plant which reduces the cost of CO2 separation and dumping. In different types of DCFCs, molten carbon fuel cell is considered to be superior due to its low operating temperature and high efficiency. This paper provides a comprehensive review of the direct carbon fuel cell technology and recent advances in this field. The paper is focused on the fundamentals of fuel cell, history, operating principle, its types, applications, future challenges, and development.

Keyword: Fuel Cell, Solid Carbon Fuel, Boudouard Reaction, Efficiency, Electrochemical Oxidation

\section{Introduction}

Since its development in 1960, fuel cell is considered to have the potential to replace the current less efficient power generation technologies [1]-[3]. This has led to an extensive research and development in the field of fuel cells [4] [5] [6]. It finds its application in power generation, transport and as portable power, 
producing a few watts to multi-megawatt of energy depending upon the dimensions and type of the fuel cell [1]. Mostly, cells are connected together in series or parallel combinations to provide desire power and voltage to the system. Different fuel cells operate at different temperatures ranging from room temperature to temperatures as high as $1000^{\circ} \mathrm{C}$. As a result, a variety of electrodes, electrolytes and other fabrication materials are available for construction and control of cell properties [7]. When compared with conventional heat engines, fuel cells have high theoretical efficiencies since their performance do not depend on temperature or pressure gradient. Moreover, lower emissions due to separate fuel and air chambers make fuel cells environmental friendly [8] . Coal is the second largest source of energy with significant utilization in thermal power plants for electricity generation [9]. Figure 1 shows the annual share of coal in electricity generation in U.S. However, the efficiency of these thermal power plants is around $40 \%$ accompanied by high carbon dioxide $\left(\mathrm{CO}_{2}\right)$ emissions. Therefore, significant improvements are needed in thermal power plants to optimize the coal consumption along with reduced environmental effects [10]. This can be done by improving the conversion technologies for coal fuel and enhancing the efficiencies of thermal power plants [11], [12]. Different systems have been proposed to overcome energy crisis and to improve the carbon capturing techniques. In the quest of more efficient and environmental friendly technologies, carbon fuel cells appears to be most promising and emerging technology [13] [14].

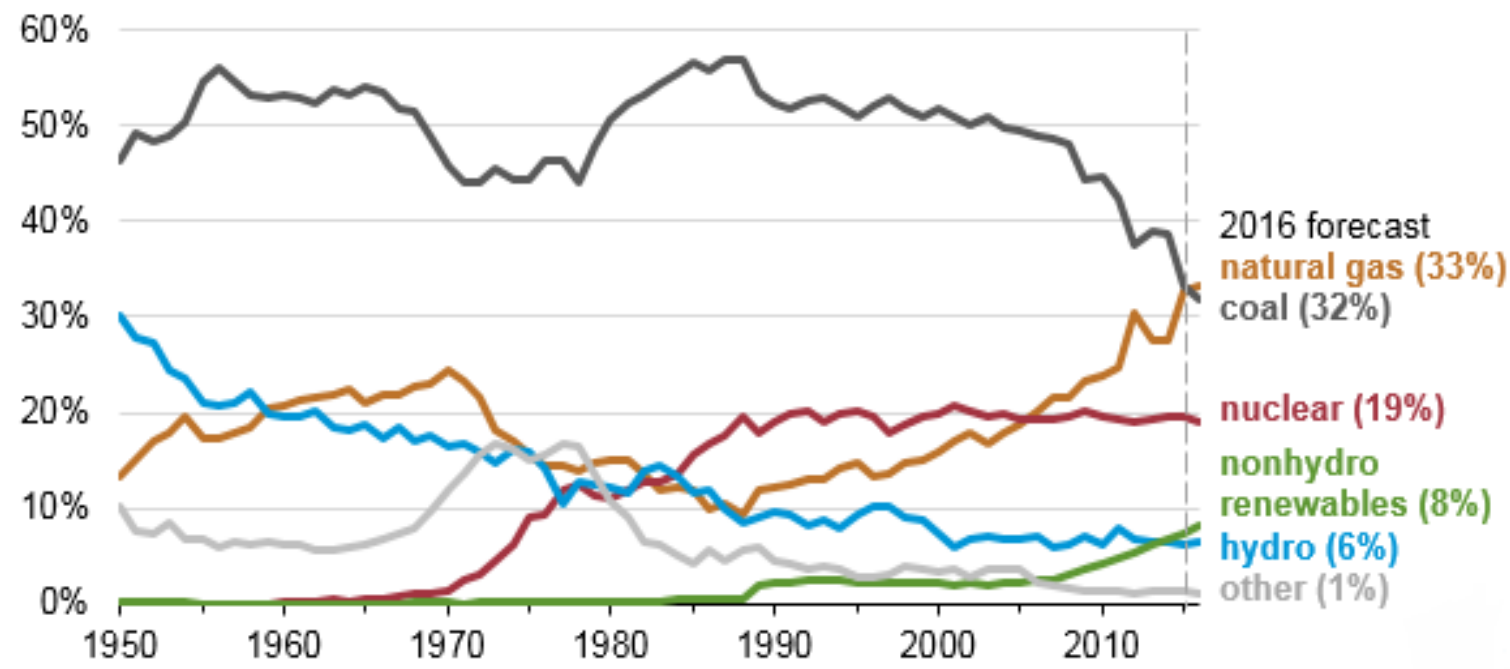

Figure 1: Annual share of total U.S. electricity generation by source [15]

A carbon fuel cell is an advanced form of fuel cell that utilizes carbon rich fuel to produce energy [16]. Solid carbon like coal and biomass is used to produce electricity in a more efficient and cleaner way [17]-[20]. An innovation in the electrodes, electrolyte and fuel allows nearly complete combustion of carbon fuel producing highly pure carbon dioxide $\left(\mathrm{CO}_{2}\right)$. Moreover, they operate at relative lower temperatures and consumes readily available carbon based fuels, making the technology more feasible to implement [20][22]. Although direct carbon fuel cells (DCFCs) are still at initial stage of development but they have a great potential to be the future power generation technology. This is because of the increasing concern on global warming and air pollution combined with the resources of coals available to be used for energy generation. The theoretical efficiencies of direct carbon fuel cells is around $100 \%$ with actual system efficiency calculated to be more than 60\% [23]. This efficiency is higher than other fuel cells and twice to that of a conventional thermal power plant. With increasing energy demands due to increase in population more efficient power generation technologies are required to meet the growing needs of energy. Figure 2 shows an expected increase of 1.5 to $3 \%$ energy demand by 2050 .

Moreover, this technology reduces the greenhouse gas emissions by more than $50 \%$. DCFCs have many benefits however there are some major challenges including: mode of solid fuel delivery to electrode electrolyte interface, corrosion of cell components, fuel processing and fuel quality requirements, overall 
Ibrahim et al., Adv. J. Grad. Res.; Vol. 6, Issue 1, pp: 14-30, July 2019

systems design, degradation rates and causes, improvement in materials performance and power densities [24].

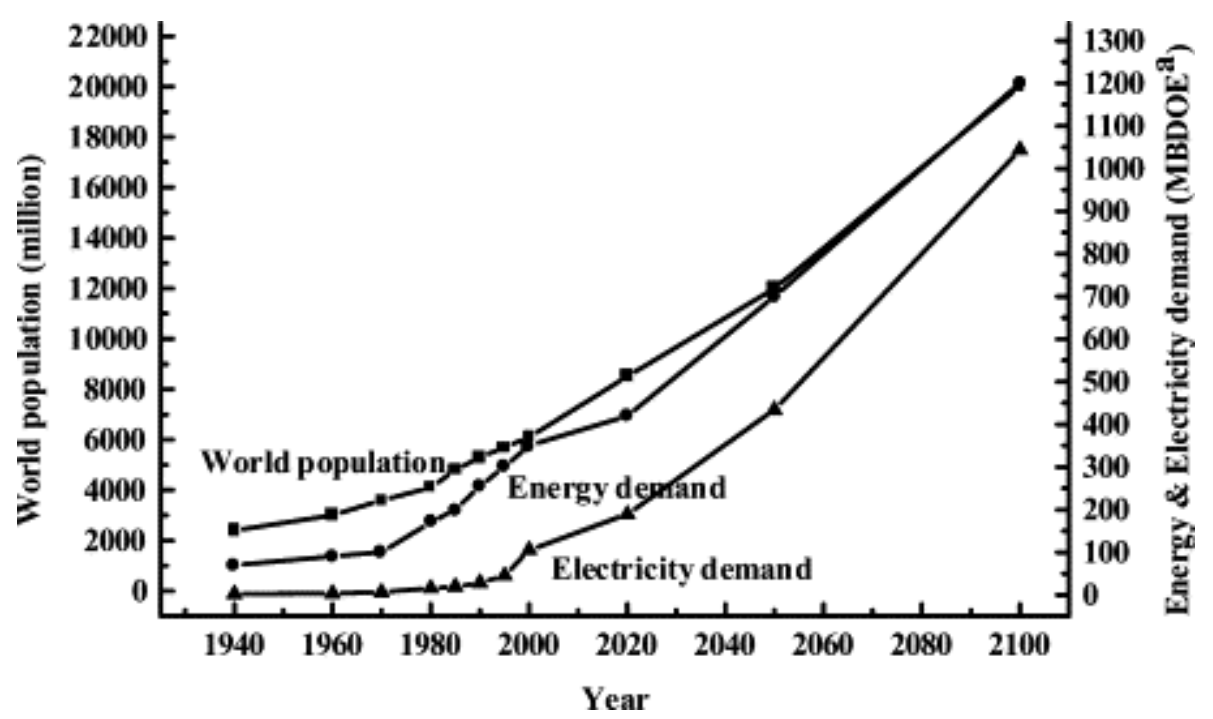

Figure 2: Estimated world energy demand (Millions of barrels per day of oil equivalent) [8]

In this paper a detailed review is performed on DCFC. The operating principle for a DCFC is actually based on electrochemical conversion of carbon to carbon dioxide. This conversion method makes them a cleaner technology that is discussed in this paper along with types of DCFCs, their fuels, application and challenges the technology is currently facing.

\section{Direct Carbon Fuel Cell}

Since the discovery of direct carbon fuel cell by Sir William Grove in 1839, researchers are trying to fabricate the perfect DCFC. In 1896, first direct carbon fuel cell was developed by an American Engineer Dr. William W. Jacques using steel pot filled with molten sodium hydroxide and carbon rod. The carbon rod acted as anode as well as fuel producing carbon dioxide. For reaction, oxygen was provided with air that was bubbled through the molten electrolyte, where the steel pot acted as a cathode. This cell is shown in Fig. 3.

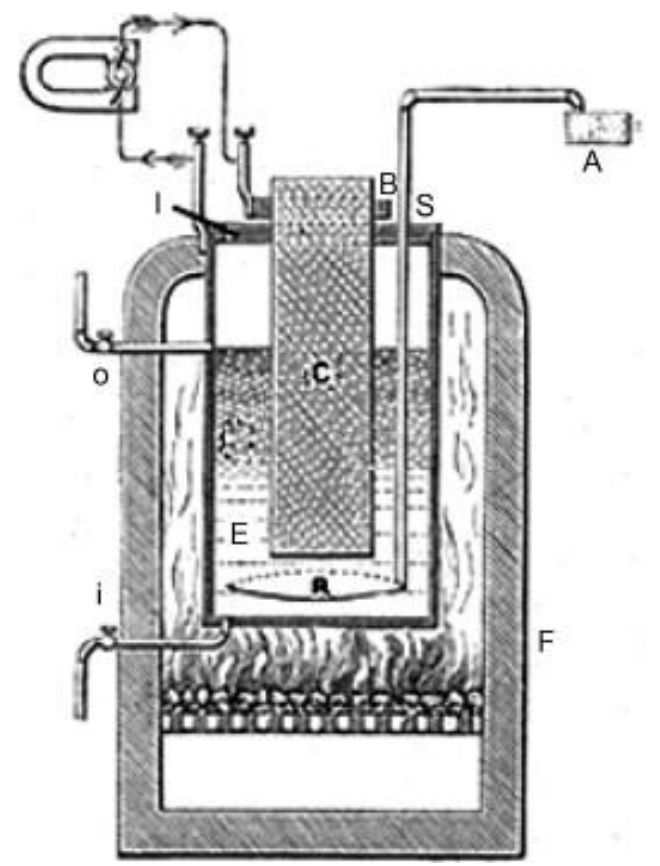

Figure 3: Direct carbon fuel cell by Dr. Jacques [25] 
Jacques operated the direct carbon fuel cell for different materials of cathode and electrolyte to find the optimum design parameters. Using his most efficient cell, he forms a combination of around 100 cell in series to generate around $1 \mathrm{~kW}$ of electricity. He claimed the efficiency of the cell to be around $82 \%$ [25]. During 1970s, Dr. Robert Weaver working at Stanford Research Institute proved that carbon can undergo electrochemical oxidation thus supported the direct carbon fuel cell technology. Later they also tested different types of carbon and found coal based anode to be most active in electrochemical reaction [26] as depicted in Fig. 4.

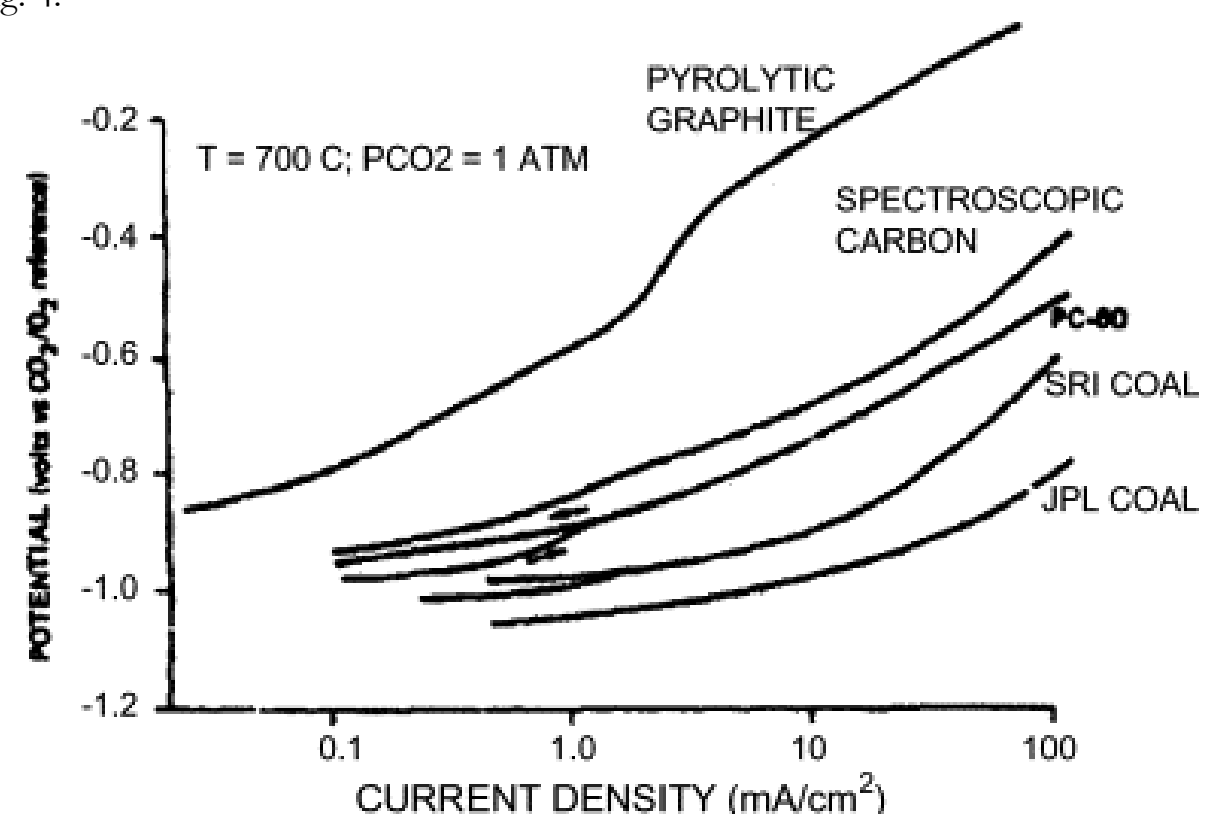

Figure 4: Performance of different carbons in a direct carbon fuel cell [27]

\subsection{Operating Principle}

Direct carbon fuel cells directly convert the chemical energy of carbon fuel to electricity without changing the phase of carbon rich fuel. It is basically an electrochemical reaction taking place in an electrochemical cell. Oxidation of fine carbon particles in electrochemical cell at high temperature of $600-900{ }^{\circ} \mathrm{C}$ produced highly pure carbon dioxide $\mathrm{CO}_{2}$ along with energy. The overall reaction is:

$$
\mathrm{C}+\mathrm{O}_{2} \rightarrow \mathrm{CO}_{2}
$$

The reaction mechanism at anode is more complex for solid carbon fuel as compared to gas fuel [28]. The reactions at anode are as follow

$$
\begin{aligned}
& \mathrm{C}+\mathrm{CO}_{2} \leftrightarrow 2 \mathrm{CO} \\
& \mathrm{O}^{-2}+\mathrm{CO} \leftrightarrow \mathrm{CO}_{2}+2 \mathrm{e}^{-}
\end{aligned}
$$

Reaction (1) is known as Boudouard reaction while reaction (2) electrochemical reaction of carbon monoxide at anode triple phase boundary. In a study by Gür and Huggins [29] yttria-stabilized-zirconia (YSZ) tube with Platinum coated electrodes were used to find reactions on anode as:

$$
\begin{gathered}
2 \mathrm{O}^{-2} \leftrightarrow \mathrm{O}_{2}+4 \mathrm{e}^{-} \\
\mathrm{C}+\mathrm{O}_{2} \leftrightarrow \mathrm{CO}_{2} \\
2 \mathrm{C}+\mathrm{O}_{2} \leftrightarrow 2 \mathrm{CO}
\end{gathered}
$$

For discharging of DCFC, the electrochemical reactions taking place at the anode of the cell were studied by Liu et al. [30] as:

$$
\begin{gathered}
\mathrm{C}+2 \mathrm{O}^{-2} \leftrightarrow \mathrm{CO}_{2}+4 \mathrm{e}^{-} \\
\mathrm{C}+\mathrm{CO}_{2} \leftrightarrow 2 \mathrm{CO} \\
\mathrm{O}^{-2}+\mathrm{CO} \leftrightarrow \mathrm{CO}_{2}+2 \mathrm{e}^{-}
\end{gathered}
$$

Similarly, Ihara et al. [31], [32] proposed the electrochemical reactions for rechargeable carbon fuel cell as:

$$
\begin{aligned}
\mathrm{C}+2 \mathrm{O}^{-2} & \leftrightarrow \mathrm{CO}_{2}+4 \mathrm{e}^{-} \\
\mathrm{C}+\mathrm{O}^{-2} & \leftrightarrow \mathrm{CO}+2 \mathrm{e}
\end{aligned}
$$


Ibrahim et al., Adv.J. Grad. Res.; Vol. 6, Issue 1, pp: 14-30, July 2019

Almost pure carbon dioxide is produced as the result of above mention reactions, provided the fuel used has high purity of carbon. This carbon dioxide can be easily captured and disposed without any need for costly gas separation technologies.

\subsection{Design and Operation}

A direct carbon fuel cell consists of an anode and cathode pack in an electrolyte. The assembly is quite simple as shown in Fig. 5. The anode is actually a carbon rod that also act as a fuel while cathode is of metallic nature usually an iron-titanium alloy. The electrolyte used can be of different types depending upon the nature of direct carbon fuel cell. The oxygen is provided through air which is preheated to operating temperature, bubbled through the molten electrolyte at the cathode. The air is usually introduced through a sparger to ensure formation of small bubbles. Moreover, to control the operating temperature a type-K thermocouple is also present in the electrolyte. Fuel cell and air is heated using ceramic fiber heaters and are insulated to prevent heat losses.

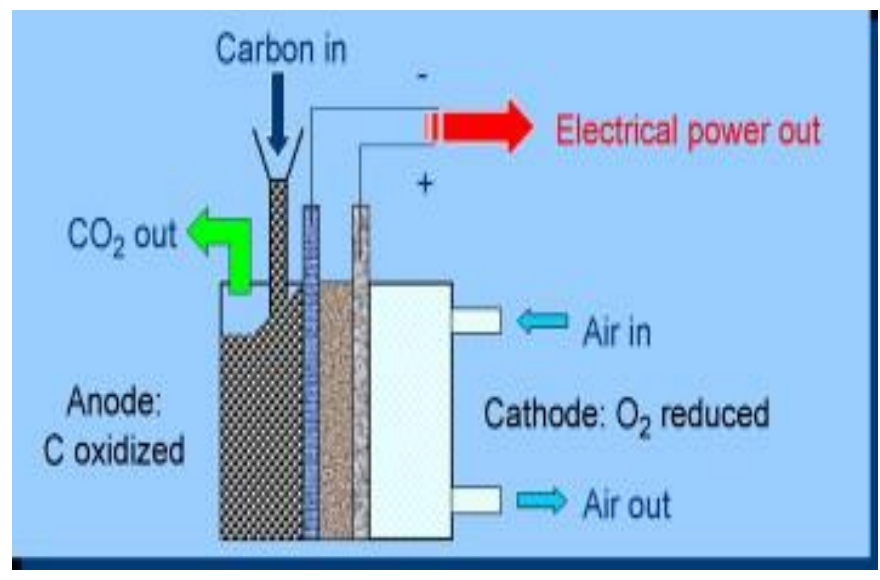

Figure 5: Schematic of a direct carbon fuel cell configuration [16]

\subsection{Efficiency}

Thermodynamic efficiency, fuel utilization factor and the voltage efficiency are used to determine the stack efficiency of a fuel cell [33]. The total energy of the fuel that can be utilize to produce electricity is called it Gibbs free energy given by

$$
\Delta \mathrm{G}=\Delta \mathrm{H}-\mathrm{T} \Delta \mathrm{S}
$$

Where,

$\Delta \mathrm{H}$ is the enthalpy of the fuel oxidation reaction, $\Delta \mathrm{S}$ is the entropy term, $\mathrm{T}$ is the temperature at which the reaction occurs. The open circuit voltage of the fuel cell is determined using the free energy $(\Delta G)$ that is available for conversion to electricity.

Where,

$$
\mathrm{Eocv}=\frac{\Delta \mathrm{G}}{n F}
$$

$\mathrm{n}$ is number of electrons transferred in the fuel cell, $\mathrm{F}$ is the Faraday constant. Badwal and Giddey showed in Fig. 6 that thermodynamic efficiency is a function of temperature.

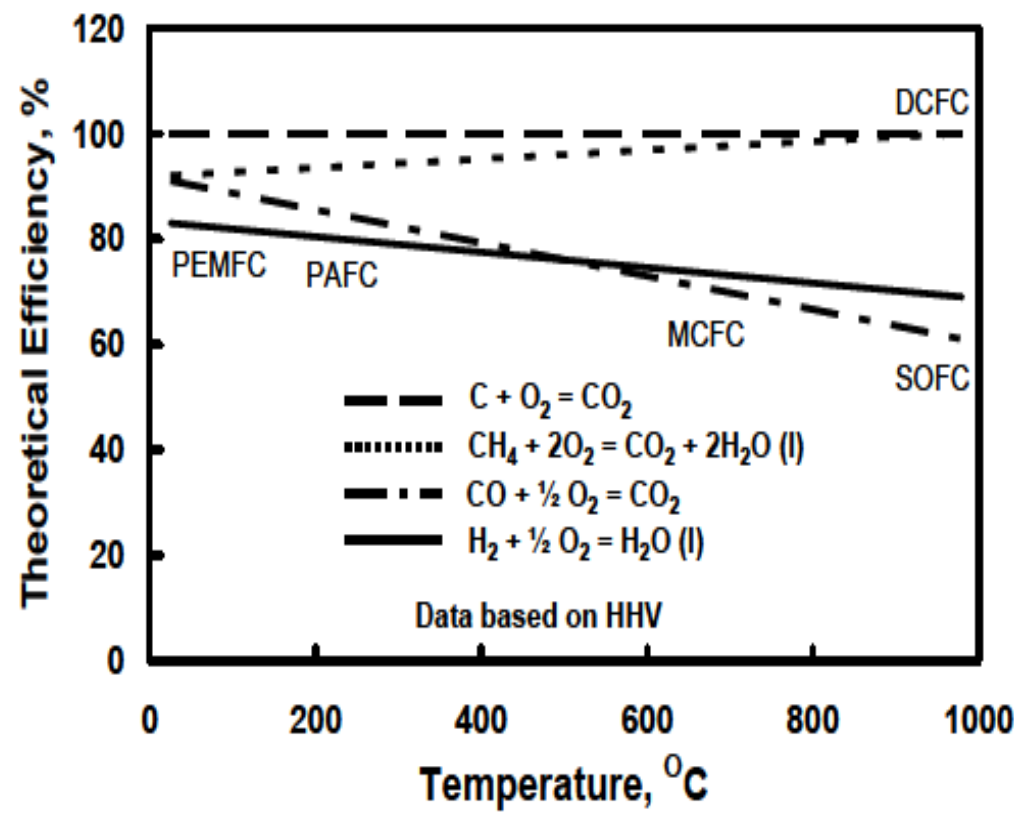

Figure 6: Theoretical efficiency for different fuels [33] 
The free energy of a fuel decreases with an increase temperature due to entropy factor. For example fuel cell efficiency for hydrogen and CO are 83 , and $91 \%$ at $25{ }^{\circ} \mathrm{C}$ while 69 and $61 \%$ respectively at $980{ }^{\circ} \mathrm{C}$ on the basis of their high heating value (HHV) [24] .

In direct carbon fuel cell, carbon rich solid fuel and products are in different phases (solid and gas). Therefore, the fuel can easily be separated and recycled in the process. Thus, almost all $(100 \%)$ of the fuel can be utilization. However, for most of the fuel cells the fuel utilization averages to 80-85\% [34].

The stack efficiency of around $75-80 \%$ is predicted for direct carbon fuel cells when the system electrical efficiencies are in the range of $65-70 \%$ considering system losses[16], [24]. An increased efficiency of 80$85 \%$ is predicted by employing heat recovery system [2]. However, at this change fuel processing and purifying techniques are not well studied which could lead to losses during coal processing, thus reducing overall efficiency of the system. The efficiency of the system is almost twice the conventional power plants and higher than some other fuel cell types [16]. Thus about 50\% reduction in greenhouse gas emissions is expected with this type of technique when compared with conventional coal fired power plants [33], [35].

\subsection{Type of Direct Carbon Fuel Cell}

The direct carbon fuel cells are classified in main three classes on the basic of electrolyte used as described in Table 1.

I. Molten salt $(\mathrm{KOH}, \mathrm{NaOH})-$ operating at $500-600^{\circ} \mathrm{C}$.

II. Molten carbonate $(\mathrm{Li}, \mathrm{Na}, \mathrm{K})-$ operating at $750-800^{\circ} \mathrm{C}$.

III. Oxygen ion conducting ceramic (doped zirconia, ceria) - operating at $800-1000^{\circ} \mathrm{C}$.

a) Fluidised bed (direct contact of carbon particles with anode).

b) Molten metal anode (carbon in contact with molten metal anode).

c) Molten salt (carbon particles suspended in a slurry).

A part from electrolytes, direct carbon fuel cells can further be subcategorized on the basis of material and design of anode and the method by which fuel is delivered to electrodes within the cell [33].

- Solid carbon - fluidised bed

- Carbon mixed with a molten metal

- Carbon mixed with a molten salt.

Table 1: Main types of direct carbon fuel cells and fuel cell reactions [24].

\begin{tabular}{|c|c|c|c|}
\hline Fuel / Anode & Electrolyte & Cathode & $\mathbf{T}\left({ }^{\mathbf{C}} \mathbf{C}\right)$ \\
\hline $\begin{array}{c}\text { Solid graphite rod as fuel and anode } \\
\mathrm{C}+4 \mathrm{OH}^{-}=2 \mathrm{H}_{2} \mathrm{O}+\mathrm{CO}_{2}+4 \mathrm{e}^{-}\end{array}$ & $\begin{array}{c}\text { Molten Hydroxides } \\
\mathrm{OH}^{-}\end{array}$ & $\begin{array}{c}\text { Air as oxidant } \\
\mathrm{O}_{2}+2 \mathrm{H}_{2} \mathrm{O}+4 \mathrm{e}^{-}=4 \mathrm{OH}^{-}\end{array}$ & $\sim 600$ \\
\hline $\begin{array}{c}\text { Carbon particle as fuel in molten } \\
\text { carbonate and anode } \\
\mathrm{C}+2 \mathrm{CO}^{-2}{ }_{3}=3 \mathrm{CO}_{2}+4 \mathrm{e}^{-}\end{array}$ & $\begin{array}{c}\text { Molten Carbonates } \\
\mathrm{CO}^{-2}{ }_{3}\end{array}$ & $\begin{array}{c}\text { Air as oxidant } \\
\mathrm{O}_{2}+2 \mathrm{CO}_{2}+4 \mathrm{e}^{-}=2 \mathrm{CO}^{-2} 3\end{array}$ & $\sim 800$ \\
\cline { 1 - 2 } $\begin{array}{c}\text { Carbon particles in fluidized bed } \\
\mathrm{C}+2 \mathrm{O}^{-2}=\mathrm{CO}_{2}+4 \mathrm{e}^{-}\end{array}$ & $\begin{array}{c}\text { Oxygen ion } \\
\text { conducting ceramic } \\
\text { electrolyte } \\
\mathrm{O}^{-2}\end{array}$ & $\begin{array}{c}\text { Air as oxidant } \\
\mathrm{O}_{2}+4 \mathrm{e}^{-}=2 \mathrm{O}^{-2}\end{array}$ & 800 to 950 \\
\cline { 1 - 1 } $\begin{array}{c}\text { Fuel in contact with molten tin } \\
\mathrm{Sn}+2 \mathrm{O}^{-2}=\mathrm{SnO}_{2}+4 \mathrm{e}^{-}\end{array}$ & & & \\
\cline { 1 - 1 } $\begin{array}{c}\text { Carbon particles as fuel in molten } \\
\text { carbonate and anode } \\
\mathrm{C}+2 \mathrm{O}^{-2}=\mathrm{CO}_{2}+4 \mathrm{e}^{-}\end{array}$ & & & \\
\hline
\end{tabular}

Along with carbon fuel cells having solid electrolyte, there are direct carbon fuel cells in which carbon is oxidize internally or externally to produce carbon monoxide (CO). Although the reaction of carbon to produce carbon monoxide is not electrochemical and thus will not produce any voltage. However, the 
Ibrahim et al., Adv. J. Grad. Res.; Vol. 6, Issue 1, pp: 14-30, July 2019

reaction of carbon monoxide to produce carbon dioxide will be electrochemical and produces voltage for the process. In this type of cell system, fuel is carbon monoxide instead of carbon. Such fuel cell can be referred as indirect carbon fuel cell. This type of system has an advantage, since carbon monoxide is produce externally therefore impurities if any, can be remove with disturbing the cell. Moreover, this type of system produces pure form of carbon dioxide which can be separated easily. However, utilization of carbon monoxide reduces the theoretical efficiency of the system [35]-[37]. The basic direct carbon fuel cell technologies are still under development. There is another but less studied type of direct fuel cell based on aqueous-alkaline electrolyte, which uses an aqueous hydroxide solution of potassium, lithium, sodium, cesium and magnesium and operates at temperature less than $250^{\circ} \mathrm{C}$ [33]. However, the performance of such cell is not satisfactory. A tree diagram for different direct carbon fuel cells is described in Fig. 7 to clarify a number of technologies under development.

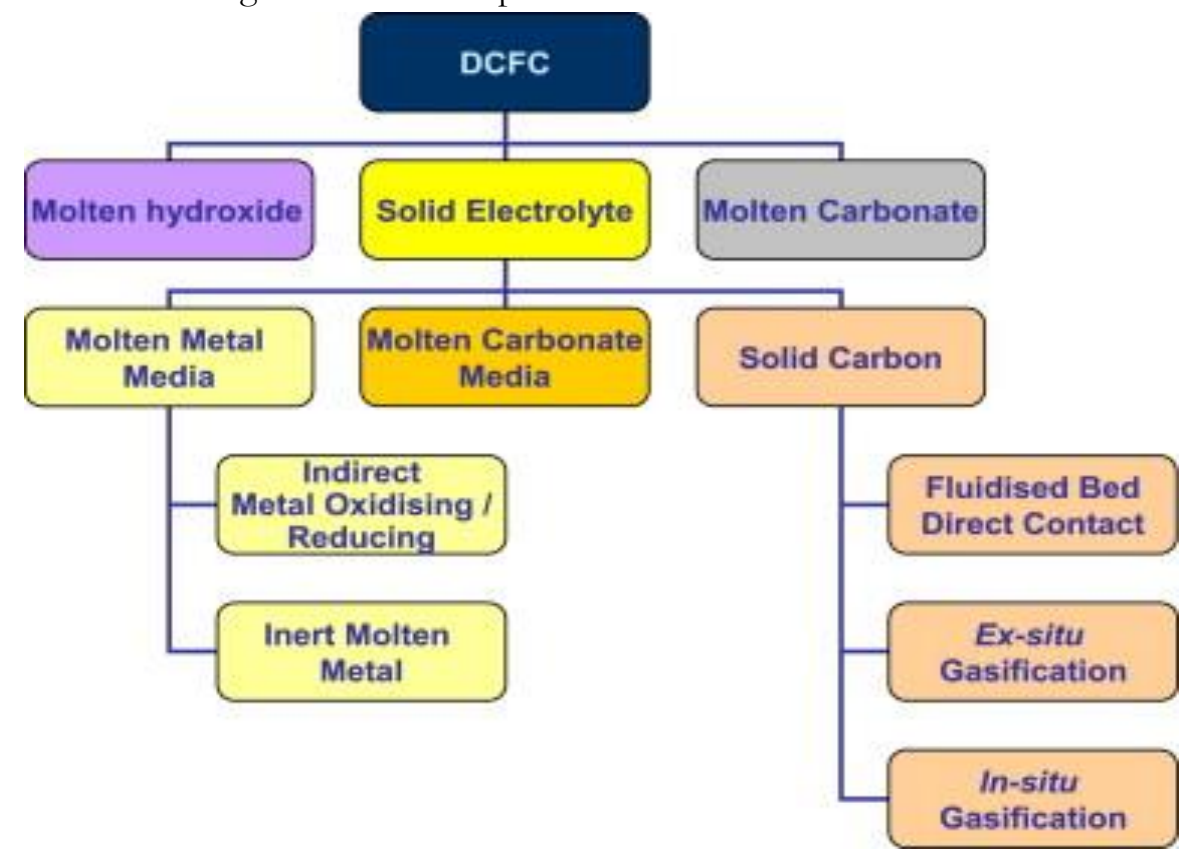

Figure 7: A tree diagram of various DCFC technologies under development [24]

\subsubsection{Molten Salt Fuel Cell}

In this type of direct carbon fuel cell molten hydroxide like $\mathrm{NaOH}$ or $\mathrm{KOH}$ is used as an electrolyte. The electrolyte is kept in an metallic pot which also act as a cathode [37]. The anode makes up of graphite or coal derived carbon is submerged in the electrolyte act as fuel. So, this carbon rod act as fuel and anode at the same time. Oxygen is supplied at the cathode by bubbling the air from the bottom of molten electrolyte[38]. Typically this type of direct carbon fuel cell operates at temperature of 500 to $600^{\circ} \mathrm{C}$ [39], [40]. Electrochemical reactions include:

\section{At anode}

$$
\mathrm{C}+4 \mathrm{OH}^{-} \rightarrow 2 \mathrm{H}_{2} \mathrm{O}+\mathrm{CO}_{2}+4 \mathrm{e}^{-}
$$

At cathode:

$$
2 \mathrm{H}_{2} \mathrm{O}+\mathrm{O}_{2}+4 \mathrm{e}^{-} \rightarrow 4 \mathrm{OH}^{-}
$$

Although molten hydroxide have a number of advantages with the main being relatively lower operating temperature high ionic conductivity, higher electrochemical activity of carbon, but has a disadvantage of the formation of carbonates [39]. These carbonates are formed by the combination of carbon dioxide and carbon with hydroxide ions of electrolyte [33], [39].

$$
\begin{gathered}
2 \mathrm{OH}^{-}+\mathrm{CO}_{2} \rightarrow \mathrm{CO}_{3}^{2-}+\mathrm{H}_{2} \mathrm{O} \\
\mathrm{C}+6 \mathrm{OH}^{-} \rightarrow \mathrm{CO}_{3}^{2-}+3 \mathrm{H}_{2} \mathrm{O}+4 \mathrm{e}^{-}
\end{gathered}
$$

Direct carbon fuel cells with molten hydroxides electrolyte can be operated at low temperatures allowing the fabrication of cell with comparatively less expensive material, thus reducing the cost of cell. Moreover, 
according to Boudouard equilibrium the dominant product from carbon oxidation will be carbon dioxide. As indicated by Goret and Tremillon the rate of carbonate formation is dependent on the concentration of oxygen ions and water concentration. As a result with an increase in water content in the cell, $\mathrm{CO}_{3}{ }^{2-}$ will reduce considerably [41].

\subsubsection{Molten Carbonate Fuel Cell}

The electrolyte in this type of cell is molten carbonate and fine particles of carbon are dispersed in the electrolyte that act as fuel. Carbonate ions $\mathrm{CO}_{3}^{-2}$ act as the carrier to carry charge [42], [43]. Because of high carbonate conductivity and good stability molten carbonates of potassium, lithium and sodium are used. The operating temperature for cell ranges from 750 to $800^{\circ} \mathrm{C}$ [44], [45]. The reactions in the cell are:

At anode

$$
\mathrm{C}+2 \mathrm{CO}_{3}^{2-} \rightarrow 3 \mathrm{CO}_{2}+4 \mathrm{e}^{-}
$$

At cathode

$$
\mathrm{O}_{2}+2 \mathrm{CO}_{2}+4 \mathrm{e}^{-} \rightarrow 2 \mathrm{CO}_{3}^{2-}
$$

A eutectic mixture of lithium and potassium carbonates is present in the cell. Anode current collector is made up of nickel and at cathode current is collected by sintered frit of fine nickel particles. Electrodes are separated by zirconia felt [39] [46]. Corrosion of metal clad bipolar plates, high cathode polarisation losses and up-scaling are main disadvantages of this type of cell. Moreover, poor understanding of relationship between carbon structure and its electrochemical activity, lack of a suitable fuel delivery system and electrolyte tolerance to high percentages of contaminants are some other issues. A molten carbonate fuel cell having particulate anode was built at Ohio State University [47], [48]. Graphite, activated carbon, and coal particles were suspended in bath of $(\mathrm{Li} / \mathrm{Na} / \mathrm{K})_{2} \mathrm{CO}_{3}$ slurry. These particles performed like anode. The current was exchanged by a gold rod that was a current collector. This cell could be operated at different conditions. With the increase over-potential, particle loading rate, temperature of cell, and rate of agitation the current density was found to increase [48].

In another study, rate of carbon monoxide formation was studied. It was found that carbon monoxide production rate for $\mathrm{K}_{2} \mathrm{O}$-added carbon black is lower and it act as inhibitor of carbon gasification as shown in Fig. 8. Carbon monoxide formation rate for $\mathrm{Li}_{2} \mathrm{CO}_{3}$-added carbon black, and $\mathrm{K}_{2} \mathrm{CO}_{3}$-added carbon black was compared [49], [50]. The results show that $\mathrm{K}_{2} \mathrm{CO}_{3}$ is a slightly more effective catalyst than $\mathrm{Li}_{2} \mathrm{CO}_{3}$ as in Fig. 9.

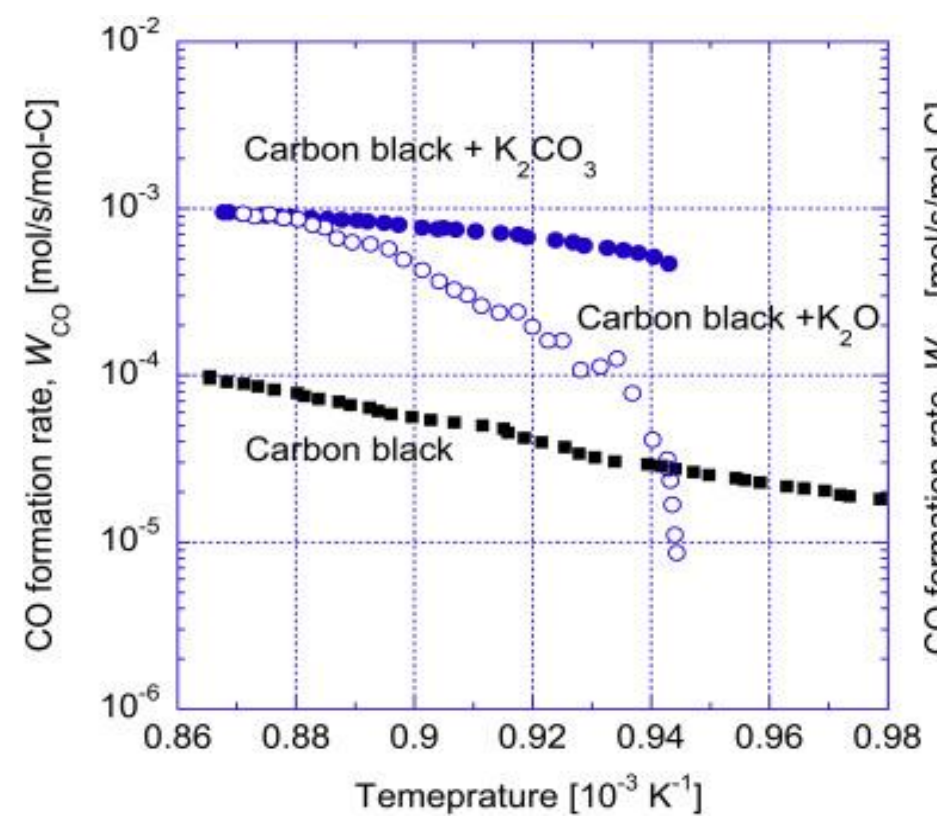

Figure 8: CO formation rate for potassium carbons [51]

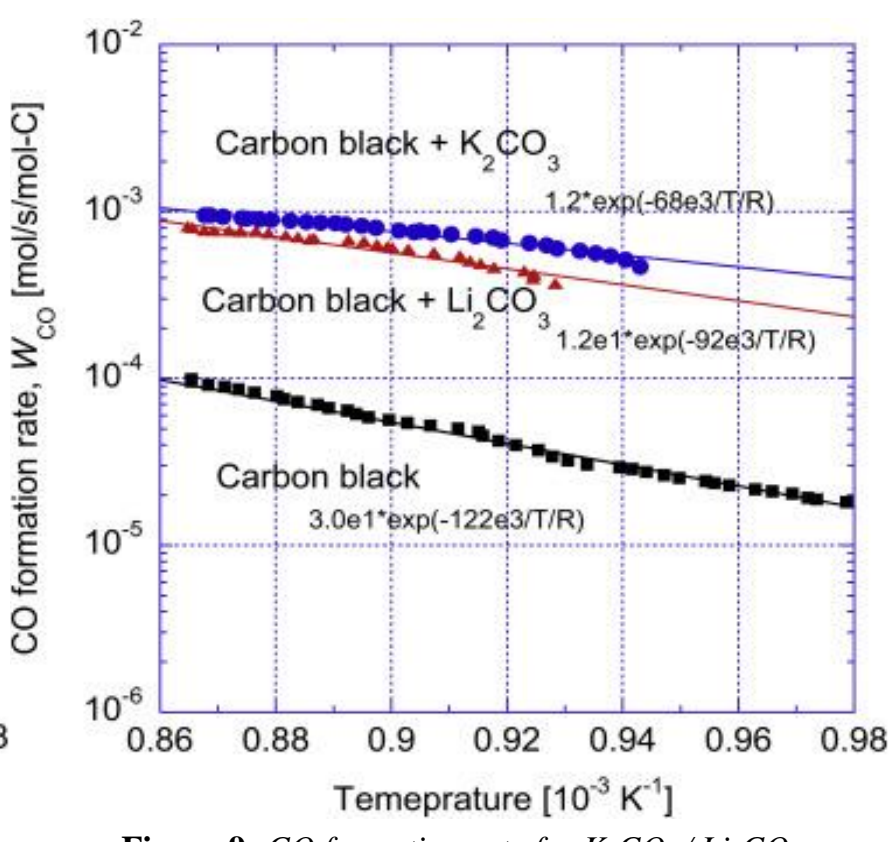

Figure 9: $\mathrm{CO}$ formation rate for $\mathrm{K}_{2} \mathrm{CO}_{3} / \mathrm{Li}_{2} \mathrm{CO}_{3}$ carbons [51] 
Ibrahim et al., Adv. J. Grad. Res.; Vol. 6, Issue 1, pp: 14-30, July 2019

Chen et al. used different ternary mixtures of $\mathrm{Li}_{2} \mathrm{CO}_{3}, \mathrm{~K}_{2} \mathrm{CO}_{3}$ and $\mathrm{Al}_{2} \mathrm{O}_{3}$ with different anode combinations in direct electrochemical oxidation with feedstocks mainly vapor-grown carbon fiber, carbon black, being flake graphite and green needle coke [52]. A mixture of carbon dioxide and air was introduced at cathode in a molar ratio of 3:5. Maximum power density with high current densities was achieved at temperature of $650^{\circ} \mathrm{C}$ using $\mathrm{Li}_{2} \mathrm{CO}_{3}, \mathrm{~K}_{2} \mathrm{CO}_{3}$ and $\mathrm{Al}_{2} \mathrm{O}_{3}$ in a mole ratio of $43.4 \%, 26.6 \%$ and $30 \%$ respectively. Researchers have also investigated the performance of direct carbon fuel cell which employed graphite and activated carbon derived from bamboo or oak-wood. To improve the activity of carbon fuel it is pretreated with $\mathrm{K}_{2} \mathrm{CO}_{3}$ and $\mathrm{HNO}_{3}$. Nitrogen was used as fluidizing gas. Nickel based current collector was used to transfer the charge as a result of anodic reaction. It was found that utilizing graphite produced limiting current density of $800 \mathrm{~A} / \mathrm{m}^{2}$ for anodic over-potentials of $0.3 \mathrm{~V}$ [53].

Molten Carbonate Fuel Cell are considered superior because of they offer high electric energy conversion and relatively low operating temperature [38], [42], [44], [54]. In a simple configuration cycle, MCFC have high conversion efficiencies (> 45\%). This leads to considerably reduced fuel consumption along with low environmental impact (reduced $\mathrm{CO}_{2}$ emissions). These properties of MCFC makes it a fit for medium to large-scale power generation. MCFC has the steepest polarization curve (V-I characteristic) which is advantageous at low current density operation [44]. Moreover, MCFC operates at a lower temperature of around $600^{\circ} \mathrm{C}$ which omits the need of expensive metal catalysts [54]. This reduces the production cost of the cell that can be used for commercial purposes [55].

\subsubsection{Oxygen Ion Conducting Ceramic Fuel Cell}

Oxygen ion conducting ceramic is used as an electrolyte in this type of cell. Stabilized zirconia $(8-10 \mathrm{~mol}$ $\% \mathrm{Y} 2 \mathrm{O} 3$, balance $\mathrm{ZrO} 2$ ) is the most common electrolyte used in direct carbon fuel cells. The cell typically operates at temperature of $800-1000^{\circ} \mathrm{C}[56]$. . There are three subcategories that use oxygen-ion conducting solid electrolyte. They differ in the anode design and the mechanism of fuel delivery to the anode / electrolyte interface.

\subsubsection{Solid Carbon or Fluidized Bed as Fuel}

In this technology a direct electrochemical reaction occurs between the oxygen ions and carbon fuel at the anode. The oxygen ions are transported through ceramic electrolyte from cathode to the anode. The reaction is as follows:

$$
\mathrm{C}+2 \mathrm{O}_{2}^{-} \rightarrow \mathrm{CO}_{2}+4 \mathrm{e}^{-}
$$

The carbon particles are in direct contact with the anode [29]. Most of the work on this type of cell is focused on button cells comprised of ceramic electrolyte disk with nickel based anode and lanthanum strontium manganate (LSM) based cathode [32]. Solid fuel delivery to anode / electrolyte interface, lack of understanding of carbon oxidation reaction mechanisms at the interface are main issues in addition with the technical issues associated with SOFC.

\subsubsection{Solid Carbon in Molten Metal as Fuel}

This type of technology employs a molten metal such as tin that act as carbon fuel carrier as well as used in anode. The reaction of tin with oxygen ions is given as follow:

$$
\mathrm{Sn}\left(\text { (iq) }+2 \mathrm{O}^{-2} \rightarrow \mathrm{SnO}_{2}+4 \mathrm{e}^{-}\right.
$$

The cell uses above reaction in the presence of oxygen at cathode have OCV of $0.78 \mathrm{~V}$. Thus, the tin oxide can be converted back to tin by a reaction with carbon fuel. The reaction would be exothermic. Electricity is produced by direct oxidation in a fuel cell that have molten tin as anode and carbon fuel. This type of cell operates at high temperature of $1000^{\circ} \mathrm{C}$. In order to maintain the contact of molten tin with carbon fuel while avoiding formation of amalgam, porous ceramic separators are used. However, use of porous ceramic separator causes excessive anodic polarization losses [33]. 


\subsubsection{Solid Carbon in Molten Carbonate}

In this technology molten carbonates containing carbon fuel act as anode and oxygen ion conducting ceramics as the electrolyte. Carbon fuel mixed with molten carbonates is supplied to anode. Various types of fuel like biomass, coal and tar can be used in this type of cell since it is a hybrid between molten carbonate and solid oxide fuel cells. The carbon is first oxidized inside the cell or externally to carbon monoxide as per following reaction:

$$
\mathrm{C}+\mathrm{CO}_{2} \rightarrow 2 \mathrm{CO}
$$

This carbon monoxide reacts with the oxygen ions at the electrode to form carbon dioxide. In the cell, the carbon particles that come in contact with oxygen ions are converted to carbon dioxide while the other ones first form carbon monoxide which is further oxidize to carbon dioxide.

\section{Fuels for Direct Carbon Fuel Cell}

Direct carbon cell used solid carbon as fuel. The performance of cell is dependent on the structure and chemical characteristics of the solid carbon fuel. In case of coal, the properties and characteristics of fuel varies greatly depending upon the source of coal and pretreatment methods used. Direct carbon fuel cells can used wide variety of fuels including coal, liquid hydrocarbon fuels, biomass and organic waste [57][59]. Some of these fuels are used directly with a little pretreatment while other require heavy pretreatment and purification to be used in direct carbon fuel cells [60]-[62]. Researcher believed that the performance of direct carbon fuel cell depends on the properties of fuel such as crystal structure (degree of graphitization), particle size and impurity, since the mechanism of carbon electrochemical oxidation is not fully understood. The oxidation mechanism varies with the type of direct carbon fuel cell. Chemical and physical properties of carbon vary with its allotropic form. Studies are conducted to understand the correlation between crystal structure and oxidation reaction mechanism. It was found that the oxygen reactivity in graphitic or partially graphitic carbons is highly anisotropic [63], [64]. Kintoshita et al. found that the rate of carbon oxidation is faster at crystal edges [65]. Moreover the rate of carbon oxidation is also affected by structural defects, dislocations, lattice vacancies and grain boundaries and as expected, highly disordered structures, such as amorphous carbon have much higher oxidation rates than highly ordered structures [63], [64]. For electrode characterization crystallite size and lattice spacing are considered as significant parameters. Studies of the reactivity of carbon showed that these factors also play significant role in direct carbon fuel cells. This has been shown by number of studies that correlate the crystal structure of carbon to its electrochemical reactivity. In general, structures with a greater degree of crystal disorder have higher electrochemical reactivity due to the greater availability of reaction sites. Crystallization index is factor on which the properties of fuel depends. Fig. 10 shows the crystallization index of different fuels.

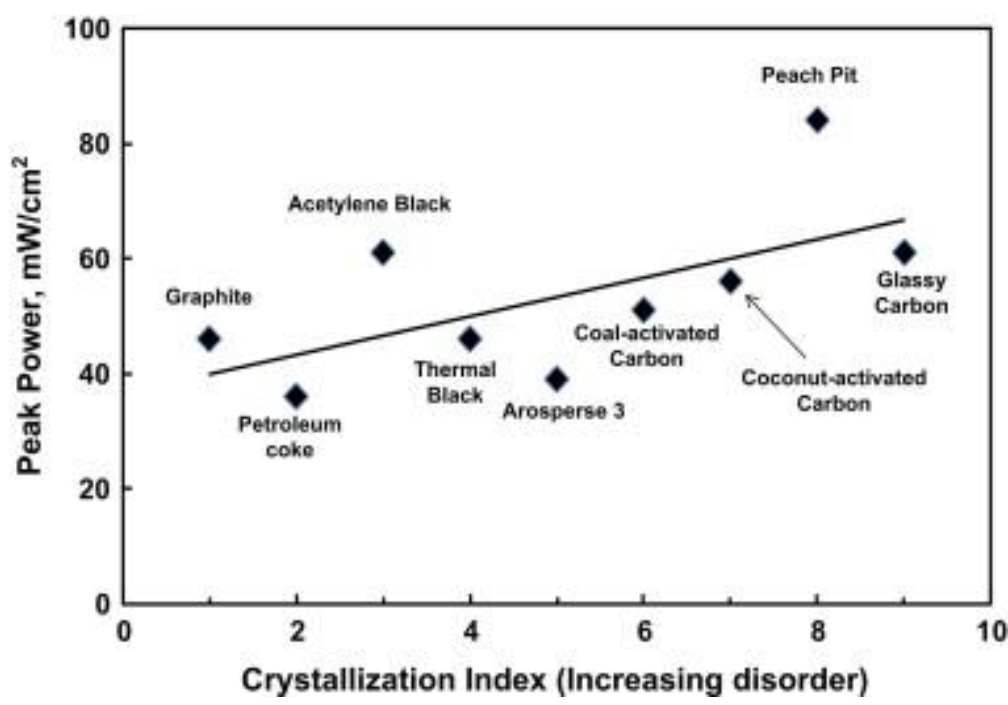

Figure 10: Performance of different carbon fuels in DCFCs

\section{Characteristics of Direct Carbon Fuel Cell}

Direct carbon fuel has many properties or features that makes it different from rest of power generation technologies. It is an emerging technology that can be used for commercial power generation through rigorous research and development. Some of the important features of the cell is discussed in this review. 
Ibrahim et al., Adv. J. Grad. Res.; Vol. 6, Issue 1, pp: 14-30, July 2019

\subsection{Reduced Environmental Impact}

The direct carbon fuel cell utilizes carbon as a fuel to produce energy by electrochemical conversion of carbon to $\mathrm{CO}_{2}$. This is an electrochemical reaction in which the only product of reaction is pure $\mathrm{CO}_{2}$ [24]. This pure gas can easily be separated and dumped without being released into the environment. No other pollutants like $\mathrm{SO}_{\mathrm{x}}$ and $\mathrm{NO}_{\mathrm{x}}$ are produced, since the cell allows only carbon to convert electrochemically.

\subsection{High Efficiency}

DCFCs have high conversion efficiencies when compared to other power generation technologies as shown in Fig. 11.

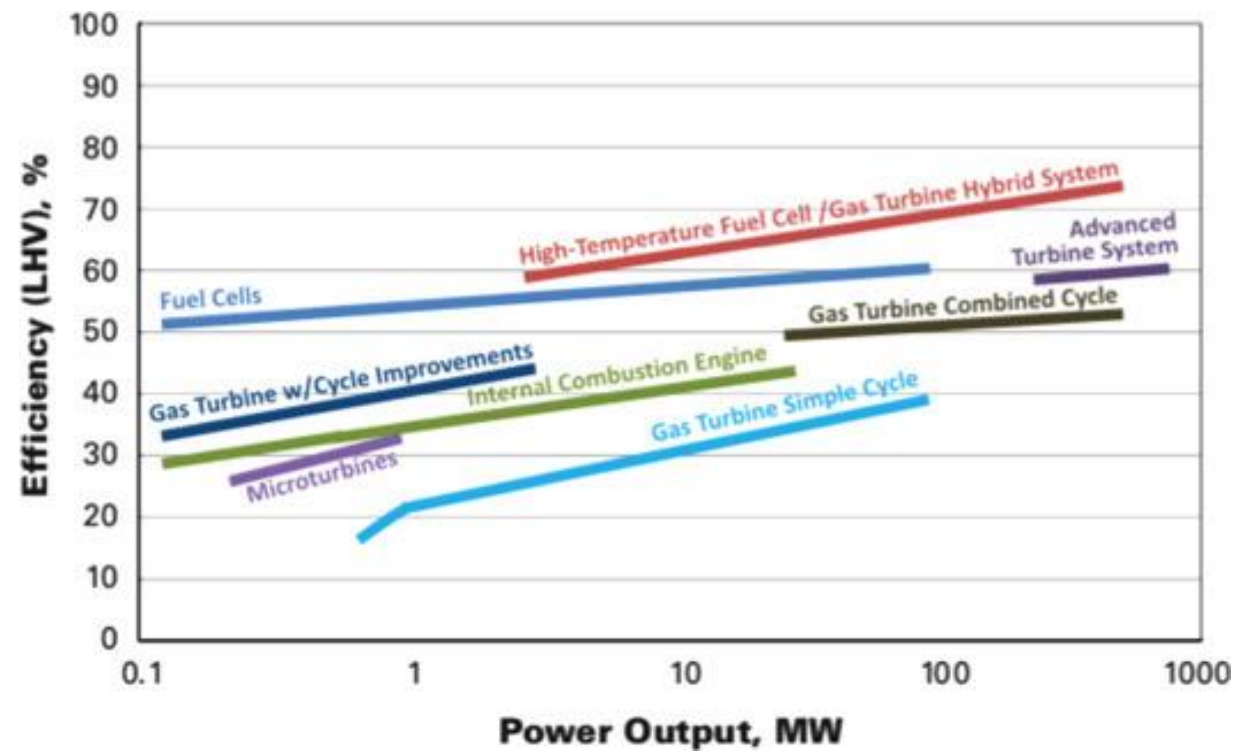

Figure 11: Efficiency comparison of power generation technologies [66].

Carnot's cycle limits the conversion of heat to useful work, but it does not affect the efficiency of DCFC as it is an electrochemical device. The operation of the cell is based on isothermal oxidation instead of combustion oxidation, therefore the maximum efficiency of the cell is calculated using Gibbs free energy. DCFC has higher efficiency because of lower number of energy transformations in the cell as compared to any combustion-based device [67]. This is because with each conversion (energy transformations) some of the energy is lost, resulting in overall reduction in system's efficiency [68].

\subsection{Modularity}

DCFCs have outstanding modularity. The output power of any fuel cell system can be controlled by varying the number of cells-per-stack and/or stacks-per-system. The efficiency of a DCFC is not dependent on the size of system prove advantageous in large-scale fuel cell systems. Independence of efficiency of DCFC from its size has an advantage of using them in smaller fuel cell systems [69].

\subsection{Fuel Flexibility}

DCFC can use a variety of carbonaceous fuels. It can used wide variety of fuels including coal, liquid hydrocarbon fuels, biomass and organic waste [57]-[59]. Some of these fuels are used directly with a little pretreatment while other require heavy pretreatment and purification to be used in direct carbon fuel cells [60]-[62]. Researcher believed that the performance of direct carbon fuel cell depends on the properties of fuel such as crystal structure (degree of graphitization), particle size and impurity, since the mechanism of carbon electrochemical oxidation is not fully understood. The oxidation mechanism varies with the type of direct carbon fuel cell. 


\subsection{Static Nature}

DCFC is inherently silent device due to its electrochemical nature. The fuel cell has limited dynamic parts that not only makes is silent, but also simplifies the manufacturing, design, assembly, operation, and analysis of the cell than that of heat engines. Such characteristic of the cell promotes its use in auxiliary power and distributed generation applications in addition to portable applications [70].

\section{Applications}

Direct carbon fuel cells have potential to be used in broad range of applications. As a result of their high efficiency, static nature, modularity and fuel flexibility, they have applications ranging from vehicles to power plants. Due to its promising nature the use of fuel cells has been increased in different sectors as shown in Fig. 12 and 13.

\subsection{Portable Applications}

Portable applications mainly includes portable power generators and electronic devices [71], [72]. Portable power generators are designed for light outdoor personal uses such as camping and climbing, light commercial applications such as portable signage and surveillance, and power required for emergency relief efforts. In electronic devices such as laptops, cell phones, etc., fuel cells cab replace battery. The power of portable fuel cells typically ranges between 5 and $500 \mathrm{~W}$ [71].

\subsection{Stationary Applications}

Residential, commercial, and industrial stationary power generation sectors can also employ DCFCs. Emergency back-up power supply (EPS) [73], remote-area power supply (RAPS) [74], [75], and distributed power generation (CHP) [76] are main stationary applications of DCFCs. Around $70 \%$ of the fuel cells are utilized in stationary applications [67].

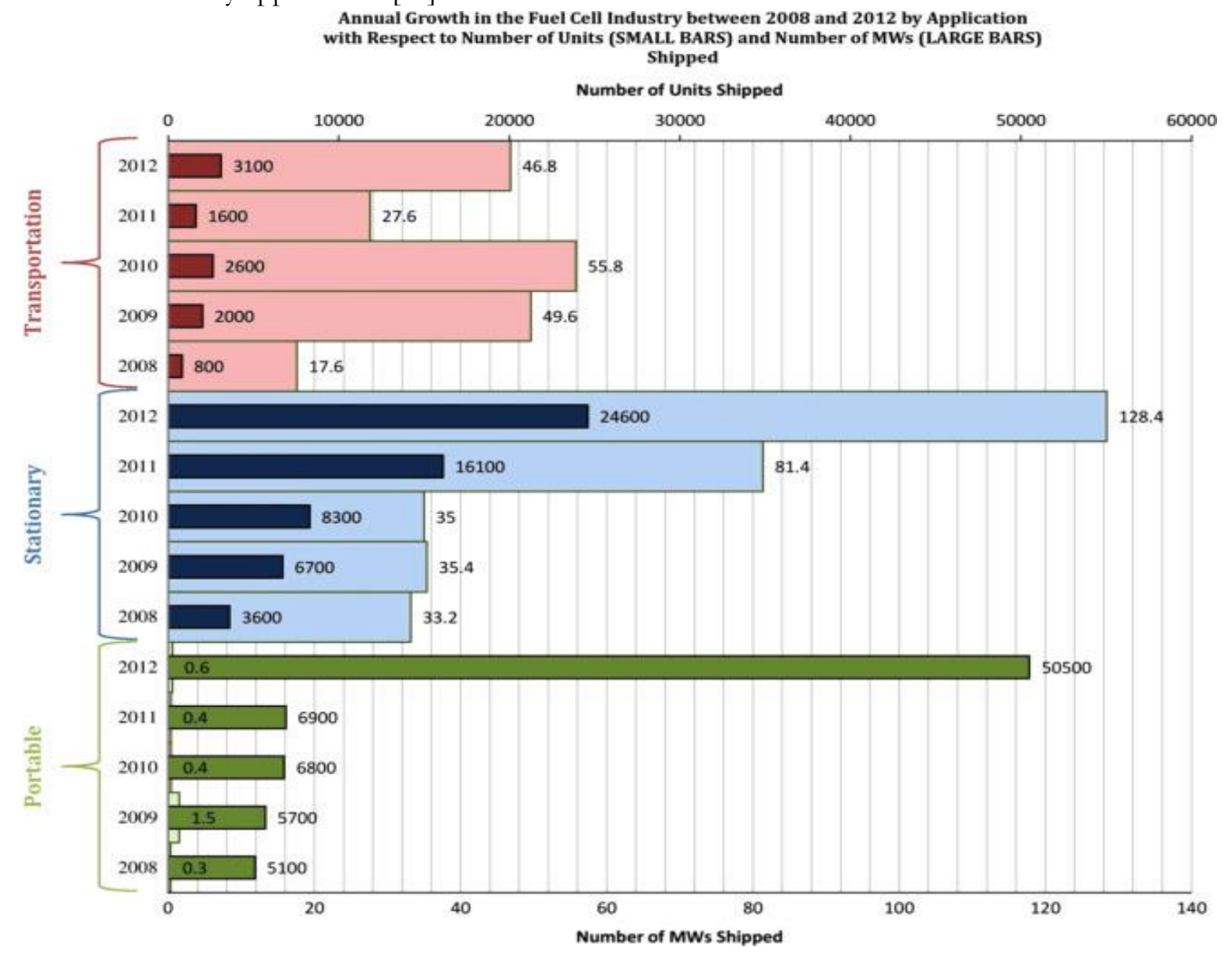

Figure 12: Annual growth of the fuel cell industry between 2008 and 2012 by application [77]. 
Ibrahim et al., Adv.J. Grad. Res.; Vol. 6, Issue 1, pp: 14-30, July 2019

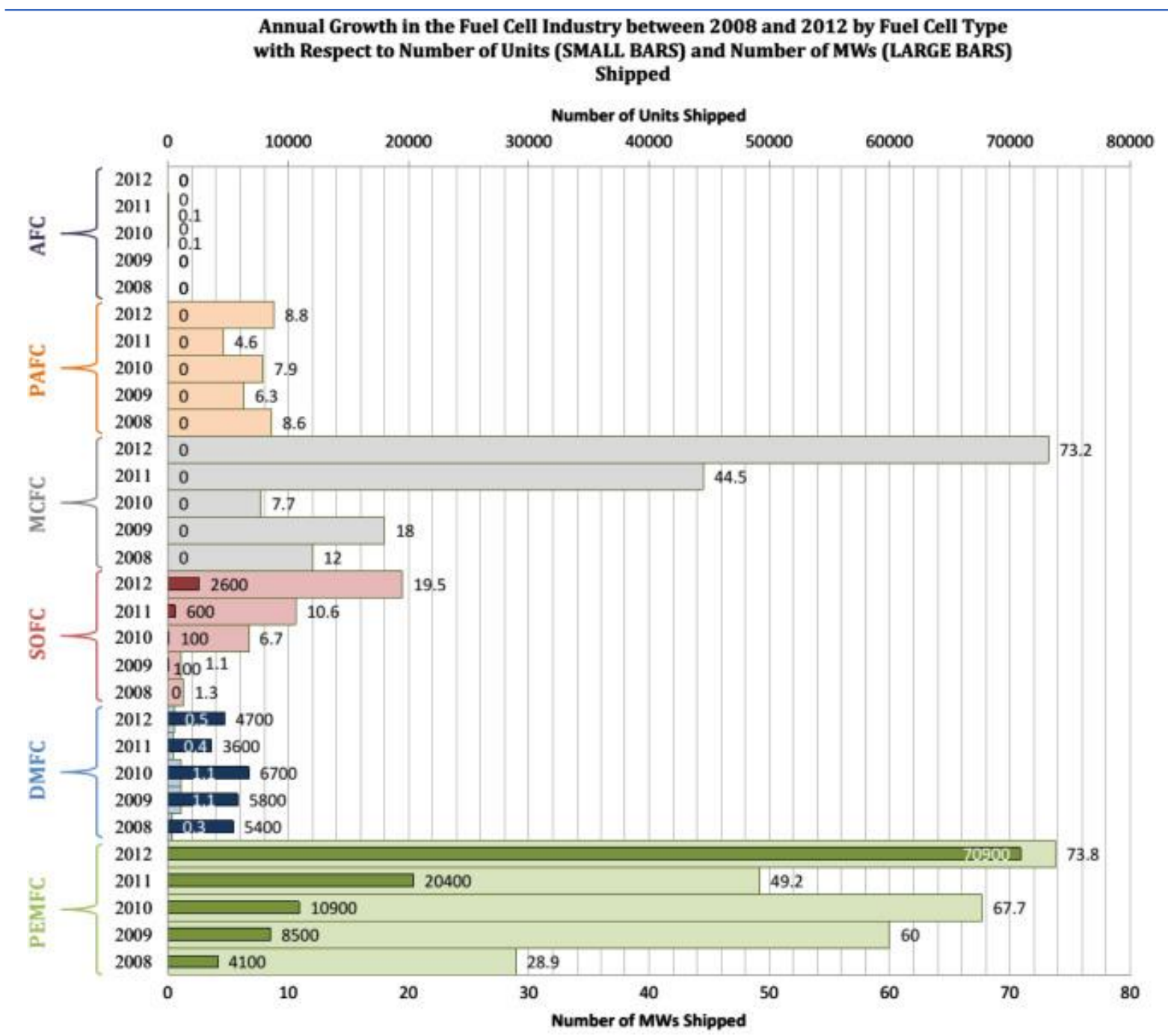

Figure 13: Annual growth of the fuel cell industry between 2008 and 2012 by fuel cell type [77].

\subsection{Transportation Applications}

The growth of the transportation industry has also increased the global greenhouse gas emissions every year [78]. This concern has served as a ground for the development of clean energy technologies like fuel cells. Currently, $99 \%$ of the vehicles get their energy from combustion engines that is a source of greenhouse gases. Contrary, fuel cells offer the transportation industry near-zero harmful emissions without having to compromise the efficiency of the vehicle. Considering the advantages such as static operation, fuel flexibility, modularity, and low maintenance requirements; fuel cells become an ideal future alternative for current combustion engines.

\section{Advantages}

Direct carbon fuel cell has many unique features. It has significant thermodynamic advantages. Because of entropy change for the cell reaction the theoretical electrochemical conversion efficiency of direct carbon fuel cell slightly exceeds $100 \%$. The chemical potentials of carbon dioxide and carbon fuel are fixed and independent of extent of conversion of the fuel, since both exist as pure substances in separate phases. This allows a full conversion of carbon fuel in single pass making the fuel efficiency of $100 \%$. This makes direct carbon fuel cell the most efficient power generation technology.

Second, different sources including coal, petroleum coke, biomass (rice hulls, corn husks, nut shells, grass, and woods) and even organic garbage can be used to produce solid carbon fuel. Coal is the most abundant fossil resource in the United States, Canada, the former Soviet Union and China. Moreover, utilization of 
carbon in direct carbon fuel cell consumes less energy and less capital as compared to the production hydrogen-based fuels by steam reforming processes. Annually, in the United States billions of kilograms of carbon black are produced by pyrolysis in the United States. Moreover, carbon releases much more energy per unit volume with oxygen $\left(20.0 \mathrm{kWh} \mathrm{L}^{-1}\right)$ as compared to hydrogen $\left(2.4 \mathrm{kWh} \mathrm{L}^{-1}\right)$, methane $(4.0 \mathrm{kWh}$ $\left.\mathrm{L}^{-1}\right)$, gasoline $\left(9.0 \mathrm{kWh} \mathrm{L}^{-1}\right)$, and diesel $\left(9.8 \mathrm{kWh} \mathrm{L}^{-1}\right)$

Third, emissions from direct carbon fuel cell are lower as compared to coal-firing power plants. In direct carbon fuel cell carbon is converted to carbon dioxide through electrochemical reaction at anode without direct mixing with air. As a result, direct carbon fuel cells have 50\% lower emissions with 10 times reduced off-gas volume compared to coal-burning power plants. Carbon dioxide is the main component of off-gas, which can be used to improve oil recovery or can be permanently stored beneath the earth's surface. This reduces the release of carbon dioxide in air. Use of direct carbon fuel cell produce electricity by coal which is in abundant in some countries like China and Pakistan, which would reduce the carbon dioxide, sulfur dioxide and nitrogen oxide emissions.

Fourth, absence of reformers and heat engines makes direct carbon fuel cells mechanically simple. It can be built near coal mine thus eliminating the need of coal transportation, saving cost and energy.

\section{Technology Status and Challenges}

Direct carbon fuel cell $\mathrm{t}$ requires extensive research and efforts before commercializing the technology, since it is in initial stage of development. Single cells or small stacks are mostly tested. Type of electrodes, method of fuel delivery within cell determines the power densities of the cell.

Following are the main technical issues that restricts the commercialization of direct carbon fuel cells:

a) Direct carbon fuel cells have usually low power densities.

b) Cells are exposed to high degradation rates that causes corrosion of various cell components.

c) Methods of fuel delivery to anode within the cell.

d) Extending the technology for large scale energy generation.

e) Production of fuel for cell utilizing low cost processing technologies.

The above-mentioned factors greatly affect the up-scaling of direct carbon fuel cell technology. The solid fuel must be delivered to anode in such a way that there is maximum interaction of fuel with electrode at electrode and electrolyte interface. The performance of cell largely depends on the properties of fuel. Therefore, fuel processing is crucial in direct fuel cell technology. The electrochemical oxidation of carbon fuel inside fuel cell is complex phenomenon. Therefore, the technology is still in its initial stages of development and need time for up-scaling.

\section{Conclusion}

DCFC is an emerging power generation technology that utilizes carbon as a fuel to produce energy through electrochemical conversion of carbon to carbon dioxide. It is an electrochemical device that is static and highly efficient device that can use a variety of carbonaceous fuels. It finds its application in small electronic devices like laptops and radio to huge power plants. The high efficiency of DCFC makes it an ideal fit for power generation applications. DCFC can be classified into different types, where Molten carbon fuel cell is considered superior because of its comparative high efficiency and low operating temperature. Direct carbon fuel cell is a cleaner technology that might be an alternative to conventional thermal power plants. However, due some technical reasons it cannot completely replace the thermal power plants but due to high efficiency it has been a topic of great interest for researchers. The production of product in different phase as compared to fuel allows up to $100 \%$ fuel consumption (by fuel separation and recycling), thus optimizing the fuel consumption. Since, the performance of direct carbon fuel cell is associated with the properties of fuel, development in fuel processing technology with further help in up-scaling of this technology. 
Ibrahim et al., Adv. J. Grad. Res.; Vol. 6, Issue 1, pp: 14-30, July 2019

\section{How to Cite this Article:}

U. Ibrahim and A. Ayub, "Direct Carbon Fuel Cell-Cleaner and Efficient Future Power Generation Technology", Adv. J. Grad. Res., vol. 6, no. 1, pp. 14-30, Feb. 2019. Doi: 10.21467/ajgr.6.1.14-30

\section{References}

[1] "Fuel Cell Systems Explained - Fuel Cell Systems Explained - Wiley Online Library." [Online]. Available: https://onlinelibrary.wiley.com/doi/pdf/10.1002/9781118706992. [Accessed: 06-Feb-2019].

[2] M. Zhao, H. Zhang, Z. Hu, Z. Zhang, and J. Zhang, "Performance characteristics of a direct carbon fuel cell/thermoelectric generator hybrid system,” Energy Convers. Manag., vol. 89, pp. 683-689, Jan. 2015.

[3] G. J. K. Acres, "Recent advances in fuel cell technology and its applications," J. Power Sources, vol. 100, no. 1, pp. 60-66, Nov. 2001.

[4] S. P. S. Badwal, "Fuel cells: an environmentally friendly power generation technology for the next century," 1998.

[5] S. P. S. Badwal, K. Foger, and M. J. Murray, "Fuel Cells: Clean Alternative Energy Technology of 21st Century,” p. $269,1992$.

[6] H. L. Hellman and R. van den Hoed, "Characterising fuel cell technology: Challenges of the commercialisation process," Int. J. Hydrog. Energy, vol. 32, no. 3, pp. 305-315, Mar. 2007.

[7] A. Kumar and R. G. Reddy, "Materials and design development for bipolar/end plates in fuel cells," J. Power Sources, vol. 129, no. 1, pp. 62-67, Apr. 2004.

[8] A. Boudghene Stambouli and E. Traversa, "Fuel cells, an alternative to standard sources of energy," Renew. Sustain. Energy Rev., vol. 6, no. 3, pp. 295-304, Sep. 2002.

[9] "Statistical Review of World Energy | Energy economics | BP," bp.com. [Online]. Available: https://www.bp.com/en/global/corporate/energy-economics/statistical-review-of-world-energy.html. [Accessed: 01-Oct-2018].

[10] L. Wang, Y. Yang, C. Dong, T. Morosuk, and G. Tsatsaronis, "Multi-objective optimization of coal-fired power plants using differential evolution," Appl. Energy, vol. 115, pp. 254-264, Feb. 2014.

[11] S. Sengupta, A. Datta, and S. Duttagupta, "Exergy analysis of a coal-based 210 MW thermal power plant," Int. J. Energy Res., vol. 31, no. 1, pp. 14-28, 2007.

[12] R. Soto and J. Vergara, "Thermal power plant efficiency enhancement with Ocean Thermal Energy Conversion," Appl. Therm. Eng., vol. 62, no. 1, pp. 105-112, Jan. 2014.

[13] C. Song, "Fuel processing for low-temperature and high-temperature fuel cells: Challenges, and opportunities for sustainable development in the 21st century," Catal. Today, vol. 77, no. 1, pp. 17-49, Dec. 2002.

[14] W. H. A. Peelen, K. Hemmes, and J. H. W. Dewit, "Carbon a major energy carrier for the future? Direct carbon fuel cells and molten salt coal/biomass gasification," High Temp. Mater. Process., vol. 2, pp. 471-482, Jan. 1998.

[15] "U.S. coal production and coal-fired electricity generation expected to rise in near term - Today in Energy - U.S. Energy Information Administration (EIA)." [Online]. Available: https://www.eia.gov/todayinenergy/detail.php?id=29872. [Accessed: 01-Oct-2018].

[16] D. Cao, Y. Sun, and G. Wang, "Direct carbon fuel cell: Fundamentals and recent developments," J. Power Sources, vol. 167, no. 2, pp. 250-257, May 2007.

[17] A. Kumar, N. Kumar, P. Baredar, and A. Shukla, "A review on biomass energy resources, potential, conversion and policy in India," Renew. Sustain. Energy Rev., vol. 45, pp. 530-539, May 2015.

[18] M. F. Demirbas, M. Balat, and H. Balat, "Potential contribution of biomass to the sustainable energy development," Energy Convers. Manag., vol. 50, no. 7, pp. 1746-1760, Jul. 2009.

[19] M. J. Prins, K. J. Ptasinski, and F. J. J. G. Janssen, “More efficient biomass gasification via torrefaction,” Energy, vol. 31, no. 15, pp. 3458-3470, Dec. 2006.

[20] A. Demirbas, "Combustion characteristics of different biomass fuels," Prog. Energy Combust. Sci., vol. 30, no. 2, pp. 219-230, Jan. 2004.

[21] "New fuel cell technology runs on solid carbon: Advancements allow the fuel cell to utilize about three times as much carbon as earlier direct carbon fuel cell (DCFC) designs," ScienceDaily. [Online]. Available: https://www.sciencedaily.com/releases/2018/01/180122091312.htm. [Accessed: 01-Oct-2018].

[22] S. K. Tiwari, V. Kumar, A. Huczko, R. Oraon, A. D. Adhikari, and G. C. Nayak, "Magical Allotropes of Carbon: Prospects and Applications," Crit. Rev. Solid State Mater. Sci., vol. 41, no. 4, pp. 257-317, Jul. 2016.

[23] J. F. Cooper and R. Selman, "Electrochemical Oxidation of Carbon for Electric Power Generation: A Review," ECS Trans., vol. 19, no. 14, pp. 15-25, Oct. 2009.

[24] S. Giddey, S. P. S. Badwal, A. Kulkarni, and C. Munnings, "A comprehensive review of direct carbon fuel cell technology," Prog. Energy Combust. Sci., vol. 38, no. 3, pp. 360-399, Jun. 2012.

[25] "Method of converting potential energy of carbon into electrical energy," US555511A, 03-Mar-1896.

[26] R. D. Weaver, S. C. Leach, A. E. Bayce, and L. Nanis, "Direct electrochemical generation of electricity from coal," Nov. 1979.

[27] Proceedings of the Third International Symposium on Molten Salts. .

[28] C. Li, Y. Shi, and N. Cai, "Performance improvement of direct carbon fuel cell by introducing catalytic gasification process," $J$. Power Sources, vol. 195, no. 15, pp. 4660-4666, Aug. 2010.

[29] T. M. Gür and R. A. Huggins, "Direct Electrochemical Conversion of Carbon to Electrical Energy in a High Temperature Fuel Cell," J. Electrochem. Soc., vol. 139, no. 10, pp. L95-L97, Oct. 1992.

[30] R. Liu et al., "A novel direct carbon fuel cell by approach of tubular solid oxide fuel cells," J. Power Sources, vol. 195, no. 2, pp. 480-482, Jan. 2010.

[31] M. Ihara and S. Hasegawa, "Quickly Rechargeable Direct Carbon Solid Oxide Fuel Cell with Propane for Recharging," J. Electrochem. Soc., vol. 153, no. 8, pp. A1544-A1546, Aug. 2006. 
[32] S. Hasegawa and M. Ihara, "Reaction Mechanism of Solid Carbon Fuel in Rechargeable Direct Carbon SOFCs with Methane for Charging," J. Electrochem. Soc., vol. 155, no. 1, pp. B58-B63, Jan. 2008.

[33] S. P. S. Badwal, S. Giddey, and S. Badwal, "THE HOLY GRAIL OF CARBON COMBUSTION - THE DIRECT CARBON FUEL CELL TECHNOLOGY,”p. 5.

[34] C. Jiang, J. Ma, A. D. Bonaccorso, and J. T. S. Irvine, "Demonstration of high power, direct conversion of waste-derived carbon in a hybrid direct carbon fuel cell," Energy Environ. Sci., vol. 5, no. 5, pp. 6973-6980, Apr. 2012.

[35] X. Li et al., "Surface modification of carbon fuels for direct carbon fuel cells," J. Power Sources, vol. 186, no. 1, pp. 1-9, Jan. 2009.

[36] A. C. Lee, R. E. Mitchell, and T. M. Gür, “Thermodynamic analysis of gasification-driven direct carbon fuel cells," J. Power Sources, vol. 194, no. 2, pp. 774-785, Dec. 2009.

[37] S. Zecevic, E. M. Patton, and P. Parhami, "Direct Carbon Fuel Cell With Hydroxide Electrolyte: Cell Performance During Initial Stage of a Long Term Operation,” pp. 507-514, Jan. 2005.

[38] L. Jia et al., "A direct carbon fuel cell with (molten carbonate)/(doped ceria) composite electrolyte," J. Power Sources, vol. 195, no. 17, pp. 5581-5586, Sep. 2010.

[39] J. R. Selman, "Molten-salt fuel cells-Technical and economic challenges," J. Power Sources, vol. 160, no. 2, pp. 852-857, Oct. 2006.

[40] G. Wilemski, "Simple porous electrode models for molten carbonate fuel cells," J. Electrochem. Soc., vol. 130, pp. 117-121, Jan. 1983.

[41] J. Goret and B. Tremillon, "Propriétés chimiques et électrochimiques en solution dans les hydroxydes alcalins fondus-IV. Comportement électrochimique de quelques métaux utilisés comme électrodes indicatrices," Electrochimica Acta, vol. 12, no. 8, pp. 1065-1083, Aug. 1967.

[42] A. L. Dicks, "Molten carbonate fuel cells," Curr. Opin. Solid State Mater. Sci., vol. 8, no. 5, pp. 379-383, Oct. 2004.

[43] N. J. Cherepy, R. Krueger, K. J. Fiet, A. F. Jankowski, and J. F. Cooper, "Direct Conversion of Carbon Fuels in a Molten Carbonate Fuel Cell,” J. Electrochem. Soc., vol. 152, no. 1, pp. A80-A87, Jan. 2005.

[44] S. McPHAIL, E. Simonetti, A. Moreno, and R. Bove, "7 - Molten carbonate fuel cells," in Materials for Fuel Cells, M. Gasik, Ed. Woodhead Publishing, 2008, pp. 248-279.

[45] L. Hu, G. Lindbergh, and C. Lagergren, "Performance and Durability of the Molten Carbonate Electrolysis Cell and the Reversible Molten Carbonate Fuel Cell,” J. Phys. Chem. C, vol. 120, no. 25, pp. 13427-13433, Jun. 2016.

[46] S. M. Konde, "Development of an Intermediate Temperature Molten Salt Fuel Cell," p. 124.

[47] D. G. Vutetakis, "Electrochemical oxidation of carbonaceous materials dispersed in molten carbonate," Ohio State Univ.,Columbus, OH, Jan. 1985.

[48] A. A. Kornhauser and R. Agarwal, "MODELING AND DESIGN FOR A DIRECT CARBON FUEL CELL WITH ENTRAINED FUEL AND OXIDIZER,” Virginia Polytechnic Institute and State University (US), Apr. 2005.

[49] Y. K. Rao, A. Adjorlolo, and J. H. Haberman, "On the mechanism of catalysis of the Boudouard reaction by alkali-metal compounds," Carbon, vol. 20, no. 3, pp. 207-212, Jan. 1982.

[50] F. Kapteijn, G. Abbel, and J. A. Moulijn, "CO2 gasification of carbon catalysed by alkali metals: Reactivity and mechanism," Fuel, vol. 63, no. 8, pp. 1036-1042, Aug. 1984.

[51] J. Y. Hwang, J. H. Yu, and K. Kang, "A study of the gasification of carbon black with molten salt of Li2CO3 and $\mathrm{K} 2 \mathrm{CO} 3$ for application in the external anode media of a direct carbon fuel cell," Curr. Appl. Phys., vol. 15, no. 12, pp. 1580-1586, Dec. 2015.

[52] M. Chen, C. Wang, X. Niu, S. Zhao, J. Tang, and B. Zhu, "Carbon anode in direct carbon fuel cell," Int. J. Hydrog. Energy, vol. 35, no. 7, pp. 2732-2736, Apr. 2010.

[53] J. Zhang et al., "Characteristics of a fluidized bed electrode for a direct carbon fuel cell anode," J. Power Sources, vol. 196, no. 6, pp. 3054-3059, Mar. 2011.

[54] “(10) (PDF) International Status of Molten Carbonate Fuel Cell (MCFC) Technology,” ResearchGate. [Online]. Available: https://www.researchgate.net/publication/237497861_International_Status_of_Molten_Carbonate_Fuel_Cell_MCFC_Technology. [Accessed: 17-Feb-2019].

[55] A. Dicks and A. Siddle, "Assessment of commercial prospects of molten carbonate fuel cells," J. Power Sources, vol. 86, no. 1, pp. 316-323, Mar. 2000.

[56] S. P. S. Badwal and F. T. Ciacchi, "Oxygen-ion conducting electrolyte materials for solid oxide fuel cells," Ionics, vol. 6, no. 1, pp. 1-21, Jan. 2000.

[57] B. C. H. Steele, "Fuel-cell technology: Running on natural gas," Nature, vol. 400, no. 6745, pp. 619-621, Aug. 1999.

[58] M. R. Predtechensky, Y. D. Varlamov, S. N. Ul'yankin, and Y. D. Dubov, "Direct conversion of solid hydrocarbons in a molten carbonate fuel cell," Thermophys. Aeromechanics, vol. 16, no. 4, pp. 601-610, Dec. 2009.

[59] A. C. Lee, S. Li, R. E. Mitchell, and T. M. Gür, "Conversion of Solid Carbonaceous Fuels in a Fluidized Bed Fuel Cell," Electrochem. Solid-State Lett., vol. 11, no. 2, pp. B20-B23, Feb. 2008.

[60] S. Nürnberger, R. Bußar, P. Desclaux, B. Franke, M. Rzepka, and U. Stimming, "Direct carbon conversion in a SOFC-system with a non-porous anode," Energy Environ. Sci., vol. 3, no. 1, pp. 150-153, Jan. 2010.

[61] A. Kulkarni, S. Giddey, and S. P. S. Badwal, "Electrochemical performance of ceria-gadolinia electrolyte based direct carbon fuel cells," Solid State Ion., vol. 194, no. 1, pp. 46-52, Jul. 2011.

[62] X. Li, Z. Zhu, R. De Marco, J. Bradley, and A. Dicks, "Modification of Coal as a Fuel for the Direct Carbon Fuel Cell," J. Phys. Chem. A, vol. 114, no. 11, pp. 3855-3862, Mar. 2010.

[63] F. Rodriguez-Reinoso, P. A. Thrower, and P. L. Walker, "Kinetic studies of the oxidation of highly oriented pyrolytic graphites," Carbon, vol. 12, no. 1, pp. 63-70, Jan. 1974.

[64] F. Stevens, L. A. Kolodny, and T. P. Beebe, "Kinetics of Graphite Oxidation: Monolayer and Multilayer Etch Pits in HOPG Studied by STM," J. Phys. Chem. B, vol. 102, no. 52, pp. 10799-10804, Dec. 1998.

[65] K. Kinoshita, "Carbon: electrochemical and physicochemical properties," Jan. 1988. 
Ibrahim et al., Adv. J. Grad. Res.; Vol. 6, Issue 1, pp: 14-30, July 2019

[66] M. Turco, A. Ausiello, and L. Micoli, "Fuel Cells Operating and Structural Features of MCFCs and SOFCs," in Treatment of Biogas for Feeding High Temperature Fuel Cells: Removal of Harmful Compounds by Adsorption Processes, M. Turco, A. Ausiello, and L. Micoli, Eds. Cham: Springer International Publishing, 2016, pp. 31-76.

[67] O. Z. Sharaf and M. F. Orhan, "An overview of fuel cell technology: Fundamentals and applications," Renew. Sustain. Energy Rev., vol. 32, pp. 810-853, Apr. 2014.

[68] R. Schlögl, Chemical Energy Storage. Walter de Gruyter, 2012.

[69] L. Palma and P. N. Enjeti, "A Modular Fuel Cell, Modular DC-DC Converter Concept for High Performance and Enhanced Reliability," IEEE Trans. Power Electron., vol. 24, no. 6, pp. 1437-1443, Jun. 2009.

[70] M. S. MATHENY, P. A. ERICKSON, C. NIEZRECKI, and V. P. ROAN, "Interior and Exterior Noise Emitted by a Fuel Cell Transit Bus," J. Sound Vib., vol. 251, pp. 937-943, Apr. 2002.

[71] K. Cowey, K. J. Green, G. O. Mepsted, and R. Reeve, "Portable and military fuel cells," Curr. Opin. Solid State Mater. Sci., vol. 8, no. 5, pp. 367-371, Oct. 2004

[72] A. S. Patil et al., "Portable fuel cell systems for America's army: technology transition to the field," J. Power Sources, vol. 136, no. 2, pp. 220-225, Oct. 2004.

[73] E. Varkaraki, N. Lymberopoulos, and A. Zachariou, "Hydrogen based emergency back-up system for telecommunication applications," J. Power Sources, vol. 118, no. 1, pp. 14-22, May 2003.

[74] M. O. Abdullah, V. C. Yung, M. Anyi, A. K. Othman, K. B. Ab. Hamid, and J. Tarawe, "Review and comparison study of hybrid diesel/solar/hydro/fuel cell energy schemes for a rural ICT Telecenter," Energy, vol. 35, no. 2, pp. 639-646, Feb. 2010.

[75] A. Bauen, D. Hart, and A. Chase, "Fuel cells for distributed generation in developing countries—an analysis," Int. J. Hydrog. Energy, vol. 28, no. 7, pp. 695-701, Jul. 2003.

[76] N. Briguglio, M. Ferraro, G. Brunaccini, and V. Antonucci, "Evaluation of a low temperature fuel cell system for residential CHP," Int. J. Hydrog. Energy, vol. 36, no. 13, pp. 8023-8029, Jul. 2011.

[77] Carter, D., Ryan, M., \& Wing, J. (2012). The fuel cell industry review 2013. Fuel Cell Today, 21.

[78] J. W. Plunkett, Plunkett's Automobile Industry Almanac 2007. Plunkett Research, Ltd., 2006.

Publish your research article in AIJR journals-

$\checkmark$ Online Submission and Tracking

$\checkmark$ Peer-Reviewed

$\checkmark \quad$ Rapid decision

$\checkmark \quad$ Immediate Publication after acceptance

$\checkmark \quad$ Articles freely available online

$\checkmark \quad$ Retain full copyright of your article.

Submit your article at journals.aijr.in
Publish your books with AIJR publisher-

$\checkmark \quad$ Publish with ISBN and DOI.

$\checkmark$ Publish Thesis/Dissertation as Monograph.

$\checkmark \quad$ Publish Book Monograph.

$\checkmark$ Publish Edited Volume/ Book.

$\checkmark$ Publish Conference Proceedings

$\checkmark \quad$ Retain full copyright of your books.

Submit your manuscript at books.aijr.org 